\title{
The Social Role of the Librarians of the Federal Institute of Education, Science and Technology
}

\author{
Caroline da Rosa Ferreira Becker \\ Federal Institute of Education, Science and Technology - Campus Rio do Sul \\ 210, Abraham Lincoln Street - Jardim América \\ Rio do Sul - Santa Catarina - 89160-202 \\ Brazil \\ carolbecker@ifc-riodosul.edu.br
}

\begin{abstract}
The study was carried out through the theoretical foundation about the conceptions and objectives of the Federal Institute of Education, Science and Technology, and also on the social role of the librarians of this educational institute. These Federal Institutes were created in Brazil in 2009 and they offer basic and higher education. This study aims at investigating, analyzing, and understanding if the librarians of the Federal Institutes of Education, Science, and Technology recognize their social roles as professionals that can contribute to the development of cognitive skills with regards to the information in the library's users. A case study was carried out with all the librarians of the Federal Institutes and questionnaires were the method used for collecting data. It should be noted in the librarians' answers that they recognize their social roles, and they act according to what they recognize. In their everyday practices, these librarians try to minimize the difficulties that the library's users face in relation to the search, location, use, assessment, dissemination, and understanding of information.
\end{abstract}

Keywords: School library, social role of the librarian, cognitive skills, federal institute of education, science and technology

\section{Introduction}

The model of Life Skills Based Education (LSBE) is an initiative of the World Health Organization (WHO) in partnership with United Nations Educational, Scientific and Cultural Organization (UNESCO). It aims at promoting the implementation of actions in order to develop the physical and mental health due to changes that have occurred in recent years. Nowadays, it can be observed that children and adolescents are not sufficiently competent to face the big challenges and pressures of the contemporary world.

This model includes three types of skills: cognitive, personal, and interpersonal. In addition to that, it also has ten categories: self-knowledge, empathy building, efficient communication, interpersonal relationships, decision-making, problem solving, creative thinking, critical thinking, managing feelings and emotions, and managing stress.

The category of critical thinking can be understood as the ability to reflect, analyze and examine the situations of personal and social life from different angles, perspectives and opinions (as cited in Paiva and Rodrigues, 2008, my translation). Yet according to Paiva and Rodrigues (2008, p.678, my translation) 'the individual who is critical is able to ask questions and not accept events without developing a careful analysis in terms of evidence, reasons, and assumptions.' However, some questions revolve around the issue of critical thinking 
such as: how do people learn to analyze and ask questions if the individuals in this society have not learned to think critically? If they have just learned how to write? If they don't have access to quality libraries? If they don't have access to schools that develop the reading skills needed? If these individuals do not understand information?

These and other factors have led 164 nations committed to Education for All to include The Life Skills Based Education Model as a basic learning need for all young people. In this sense, the LSBE refers to an interactive process of teaching and learning that allows the student to acquire knowledge and to develop healthy behavioral attitudes and skills. This is an education that helps young people to develop their critical thinking and problem solving skills.

The school library, which is an information center of the school, can be a place where we can develop these life skills, mainly the cognitive skills with regard to information. In a society where there are loads of information broadcast in a short period of time, young people have difficulty seeking, finding, using, assessing, disseminating, and understanding the information.

In Brazil, the reality of school libraries is precarious. The doors are mostly closed, the collections are outdated, and what we can see is much more a physical depository of materials for teachers and coordinators who use this place whenever is needed. A total of 149,968 establishments with Brazilian public elementary education in 2003 , only 34,307 (22.88\%) had libraries (BRAZIL, 2008a, my translation). In addition to that, from the 100 school libraries in Brazil, only two have librarians (BRAZIL, 2005, my translation).

The creation of the Federal Institutes (FI) in Brazil by means of Law number 11.892, on December 29th, 2008b, was a milestone in the history of school libraries in Brazil. This is because the policy implementation of the Fls has created libraries and hired librarians to work in these libraries.

Based on information provided by Artur Moreira via e-mail on June $26^{\text {th }}, 2013$ (Chairman of the Libraries of the Brazilian Federal Education, Science and Technology - CBBI), there are currently 375 registered librarians in a list of emails of CBBI. However, Artur believes that there should be an increase of $25 \%$ to $30 \%$ of librarians who work in Fls who are not registered in the list of e-mails. As a result, it can be said that the Fls have approximately 450 librarians working in libraries of more than 400 campuses spread across all Brazilian states.

On the one hand, the Brazilian university libraries have librarians, due to the law that requires the presence of this type of professional in the library.

On the other hand, since the libraries of the Fls are managed by professional librarians, the goal of this research is to investigate, analyze, and understand whether the librarians of the Federal Institute of Education, Science and Technology recognize their social role as professionals who can contribute to the development of cognitive skills related to information of library users.

Although libraries are recognized as social organizations that provide information services to society as a whole, in the case of the librarians who work in the Fls a question may be asked: do they they recognize their social role?

Even though there are librarians in the libraries of the Fls, it may be that these professionals do not have the understanding of their social role; perhaps it is because the curricula of the library and the history of the library profession, which is very focused on the technical activities of processing the library's collection. 
Depending on the role of the librarians and their understanding of their social role, these professionals can perform mediation, helping users and the local community to seek, use, find, and understand information; and it may even contribute to the training of users and readers of this community. Otherwise, it is also possible that the librarian acts as a guardian of the library concerned with the activities of technical processing of the collection, focused on keeping order and silence in the library, and forgetting the main reason there are libraries: for the users and for the community that attend them.

Another issue that justifies this research is the challenge of the librarians of the Fls that may perform their profession by serving an audience quite comprehensively, i.e. students who study from elementary school to higher education. In this sense, the environment of these libraries must be suitable for stimulating new discoveries in information to the library users in school as well as to the users of the university's library. According to UNESCO (1997, p.6), more recently many authors have emphasized that the basic activity to be considered in cognition is the processing of information. Thus, the understanding of the librarians on their social roles is crucial because it can make these professionals develop their work in a sense that the library users gain more autonomy in seeking and using information, especially because they are also part of an information society.

\section{The Federal Institutes of Education, Science and Technology: Conceptions, Objectives and Mission}

The draft constitution of FIs is presented as progressive, and sees in education the possibility of social change and a greater sense of life, featuring in it a policy of social transformation.

The intention is to overcome the Althusserian view of the educational institution as a purely ideological apparatus of the state, the one that reproducts values of the ruling class and reflects it through the conflicting interests of a class society. The Federal Institutes reserve to the protagonists of the educational process, beyond the undeniable role of dealing with scientific and technological knowledge, a praxis that reveals the places occupied by each individual in the social fabric, which brings out the different ideological conceptions and assures to the subjects conditions to interpret this society and exercise their citizenship from the perspective of a country founded on justice, equity and solidarity.

(BRAZIL, 2008c, p.21, my translation)

The Fls, which is based on humanistic and technical training, works in various levels and types of education (basic education, vocational, and higher) in favor of the social good and on behalf of knowledge, culture, labor, science, and technology. Much has been questioned in relation to technological and professional education, due to the fact that it is treated as a functionalist approach to meet the objectives set by the ruling class and the capital. The commodification of education contributes to the subjugation of humans and leads them to be manipulated.

Professional and technological education should have as main elements: to be humanizing with the technical education in the service of good living; to be a model in training to create a culture of understanding and responding to the needs of society; to foster innovative experiences and economy of solidarity and cooperation. (verbal information provided by Julio Nicolas Rogero Anaya, at II World Forum of Professional and Technological Education, in Florianópolis, on May $30^{\text {th }}$ 2012.)

As a public institution, the policy of the Fls is a commitment of the society as a whole, establishing equality in diversity (social, economic, geographical, cultural, etc.). In addition to 
that, it is coordinated with other policies (employment and income, sectoral, environmental, social and, also, educational development), which creates an impact on this universe. (as cited in BRAZIL, 2008c, my translation)

In relation to local and regional development, the Fls should work towards the construction of citizenship and face the challenge of 'becoming places of reference of being together, of working collectively, of the exchanging meanings, and finally, of the relations of meaning negotiations which, extending beyond the institutional space, constitute the core of a more democratic experience.'(BRAZIL, 2008c, p. 25, my translation)

As a principle in their political-pedagogical proposal, the Federal Institues should offer basic education, mainly with high school courses integrated into professional education level as a technical school; technical education in general; higher courses in technology, and bachelor's degrees in areas where science and technology are decisive components, in particular the engineering courses as well as lato and stricto sensu postgraduate programs, while ensuring the initial and continuing training of workers and future workers.

The Fls constitute a new educational model created by the Ministry of Education in late 2008 and are part of the Federal Network for Professional Education and Technology. It is important to note that the Fls were created from existing structures in the Federal Centers for Technological Education (known as CEFETs), in the decentralized units Teaching (known as UNEDs) in the Agrotechnical Schools, in the Federal Technical Schools, and also in the schools linked to the universities.

Among the principles of implementation of Fls (from the initial clarifications on the concepts and guidelines that drive this new model of education), the social commitment of these institutions is clear. In fact, not only is the institution committed to society, but also to the group of people that works for this educational institute. Since these Fls were formed from existing structures, this group of people had to readapt to a new educational context that provided an opportunity of a greater range of courses offered to society, which include courses from initial training to graduate. Most of the educational institutions that became FIs resembled technical schools because they already offered courses from high school to technical education. In addition to that, the infrastructure of these institutions was primarily for the interest of that particular public school. With the implementation of the Fls, parts of these schools join with each other to create a campus; those are subordinated to one of the 38 rectors of Fls created in Brazil.

\section{The Social Role of the Librarians}

The social role of the institutional group should be in line with the principles of implementation and consolidation of the Fls, but the theory falls far short from the practice. Taking into account the case of a public institution, it can be difficult to reconcile theory and practice, due to the lack of professionals committed to their work and also to the social role they can perform. Vandenbos (2010, p. 681, my translation) explains the meaning of the social role as 'the functional role played by an individual who holds a formal position in a social group, such as the role of teacher.' With the new reorganization that occurred in the Federal Network of Technological Education due to the creation of the Fls, the functions of individuals involved in this educational institute have become broader because the educational modalities offered were also expanded. Thus, in the case of the librarian, who previously only managed a school library, now he/she also has to manage a university library.

The concern with the organization of the libraries in the institutions that have been incorporated into the Fls was first presented in the Brazilian literature through the studies of Jose Maria de Araujo Souza. He wrote, in 1965, the book Instalação de Bibliotecas em 
Escolas Técnicas Industriais (Installing Libraries in Industrial and Technical Schools, my translation) in 1965. Moreover, Doris de Queiroz Carvalho also wrote a book entitled Manual de Serviços para Bibliotecas de Escolas Técnicas Industriais (Manual of Services to Libraries in Technical and Industrial Schools, my translation) in 1966. In 1970, she published a revised version of the book previously mentioned named Bibliotecas de Escolas Técnicas Industriais: Manual de Organização e Funcionamento (Libraries in Industrial Technical Schools: Organizational and Operational Manual, my translation).

According to Carvalho (1970), there were 23 libraries installed in the Federal Technical Schools. The objectives of these libraries were also presented by Carvalho (1970) who claims that they possess an enabling environment of teaching, which provide collections suitable for use by teachers and students; it is also an environment in which teachers and students could develop a taste for good reading, and the habit of using books; and an environment in which teachers and students could also develop the ability to conduct research, enriching their personal experiences and making them better prepared to advance in their professions.

Carvalho (1970) also points out the functions of the librarians as the acquisition of publications and the organization of this material suitable for use by students and teachers, the provision of the collection to enhance and enrich school programs, teaching students how to use the library collection, fostering a love of reading, and developing the research capacity of the students. In addition to that, Carvalho (1970) states that the library must also provide the following: an updated collection on the subjects in the curriculum; study and research rooms; free access to the library, where the collection is organized according to the subject it relates; the ability to borrow from the collection; reading courses, with living room and reading projects group; reading orientation; and video room for exibitions of educational films.

As a matter of fact, 42 years ago, it was once thought what should be the libraries of the institutions that comprised the Professional Network for Professional Education and Technology: welcoming and organized environment, with a vareity of materials in the collection; professionals committed to teaching students and providing guidance in reading and research; free access to information, with the freedom to use the services offered to the library's users. Libraries that have environments with these characteristics and librarians with these functions possess the qualities necessary to serve their users of basic, professional, and higher education.

In the literature there are few bibliographies that address the libraries of the former CEFETs, UNEDs, Agrotechnical and Technical Schools, certainly because the history of these institutions have undergone several changes over the years, and also because most of these organizations worked in isolation and are linked directly to the Ministry of Education.

At this time, with the creation of Federal Institues, several libraries join each other in order to be part of the same Institute, which facilitates a dilaogue among the librarians who work in these libraries, converging the actions of these professionals and referrals from these libraries. In 2011, the Brazilian Commission of Libraries of Federal Institues, known as CBBI (National Forum, 2011), was created with representatives from all regions of the country, demonstrating the need to think and articulate actions for these libraries.

Pacheco (2009, p.8, my translation) emphasizes that the Fls 'are characterized by necessary boldness and innovation for a policy and a concept that seek to antecipate in the present debate the basis of a contemporary school of the future and committed to a society radically democratic and socially fair'. This daring and innovation also reflect the role of librarians who work in these libraries. As an institution of contemporary educational future and committed to society, the Federal Institutions should offer via libraries an updated informational environment, organized and planned. This environment may give everyone the 
means to access information on different media, with librarians who teach the users to understand, find, assess, use, and disseminate information. Most important, however, is to empower the users to have autonomy in their use of information and make them able to transform this information into knowledge, quality of life, and social equality.

The need to rethink about the social role of librarians of Fls is externalized in the voices of librarians who participated in the VI National Forum of Librarians of Federal Institues, which occurred in the city of Petrolina, in Pernambuco, when they suggested the theme for the VII Forum "The identity of the libraries of FIs" and also "The skills and the profile of the FIs" librarians"(National Forum, 2011).

In order to analyze the social role of librarians of Fls, first it is necessary to study the typology of libraries of these Institutes. Generally speaking, libraries are classified according to some specific features in relation to the users and the collection, and because of those, there are various types of libraries: for children, college, school, specialized, public, mixed, community, digital, among others.

Santos, Hoffmann, and Boccato (2011, p.1, my translation) emphasize that libraries of Fls 'go in search of their identity construction, comprising a junction of types and looks to be built and refined.' Furthermore, Santos et al. suggest that libraries of Fls should be studied by the type of libraries: school, specialized, and university.

A new classification of the types of libraries is presented by Moutinho and Lustosa (2011), when they classify the libraries of Fls as technological. Moutinho and Lustosa (2011) also emphasize that libraries should be prepared to receive the users for each type of education offered by the Fls, i.e. basic, professional, and higher education.

Given these classifications, it can be observed that the types of libraries that the Constitution of FIs requires start to be tested: school, specialized, technological, and higher education libraries. It is important to notice that the range of typologies will be broad due to the fact that there will be also a wide range of courses offered by these institutions.

Luz (2007) emphasizes that the libraries are not normally included in the planning, budgeting, and institutional policy decisions, being excluded from the institutional events. The librarian that fulfills his/her social role must be able to make the interests of the library and information policy be on the same level of the institutional planning and political-administrative activities. Luz (2007) also reports that the librarian should be competent in making the library an instrument used to force the political and institutional goals.

Dante (2000) states that the professional skills should be associated with the library, administration, technology, information, communication, businesses, and with the general culture.

The librarian profession, which appeared in 1962, was in the course of time having to upgrade because of the changes that occurred in the socio-political-economic setting and, especially, in the Brazilian technology.

The late 80's brought to the Librarianship a question that has not yet found a definitive answer: who is the information professional able to face challenges and difficulties caused by large changes in the arrival of the information age?

(Valentim, 2000, p.107). 
According to the Brazilian Classification of Occupations (CBO), the librarian is the information professional. And as a description of the activities of these professionals, CBO presents:

Provide information in any medium; manage units like libraries, documentation centers, information and related centers, besides information systems and networks. Deal technically and develop information resources; disseminate information in order to facilitate access and knowledge generation; develop studies and research; perform cultural diffusion; develop educational activities. They can provide advisory and consulting services.

However, Almeida Júnior (2000, p. 42, my translation) argues that 'the idea of the information professional is not specific nor a prerogative of the librarian, on the contrary, it identifies a range of professions that deal with information.' In this line of thought, Souza (1997) reports that the librarians do not seem to know how to build their citizenship, even with all the right to information and reading (because they say they are information and library). By considering themselves as irreplaceable in the library or in the informational activities is a way to ignore the dynamics of society. It is not only the right to information and reading that should be discussed, but also the practice of reading and the use of the resulting information. Regarding the use of information, Silva and Cunha (2002, p.82, my translation) present the role of the librarian as the manager of information:

The most important role of the librarian in the twenty-first century will be the one of information managers. The importance of this task can be well placed: the big problem of this century is the overabundance of information. So if we do not have systems and strategies to access information or we are unprepared to access them, what does much information serve for? What will the technology serve for, if most people do not know how to use it or they will not have access to it? Computers and intelligent data processing can even take part in this task. However, the organization and manipulation of all this information requires instructions, and at this point the librarian can help. Such task will directly influence the lives of all people and will require an educational, intellectual, social, and technological skills.

Baptista (2009) considers that among the professional groups involved in the processing of information, the librarian seems to be the most affected in his/her functions. The reason for these changes is the result of developments within the library as an institution, which reflects on the diversification of information media, or as a result of the inevitable changes that technology introduced in the library routines. However, despite these changes have affected the librarianship, the librarians are not always well prepared to rethink their practices and their social functions. Regarding this subject, Almeida Júnior (2004, p. 81, my translation) states:

[...] the librarian believes that current technologies provide, in fact, the celebrated, increased, and widespread "democratization of information". It is given the right to everyone, from the New Information and Communication Technologies (NICT), to access, use, and own existent information in the virtual universe. The democratization of information, the extent to which it is understood and disseminated, is a fallacy, and it exists only in discourse, which aims to present a distorted reality, distorted ideologically.

Almeida Júnior (2004) argues that librarians should act as mediators of information, making the users understand and assimilate the informational content, which is presented to them in a very large amount. Besides, reading becomes the primary task of these professionals. In 
order to encourage reading, the librarian should be, above all, a great reader. A love of reading is not just for academic training, but it is necessary for continuous self-education through research, reflection, and intellectual growth.

The librarian, for the specificity of his/her action, should date books, always demonstrating a personal passion for reading. For this, you should think hard about his/her own training. I mean: ask if your path and academic training processes are enabling the development of reading habits and increase your reading repertoire. (Silva, 1999, p.128, my translation)

Finally, the librarian profession is still very much ruled by technical concepts of the profession, it does not expose sufficiently its social and educational functions in order to help the community of users in the correct use of information sources, to encourage the student or researcher to read and use the library, and especially to develop a taste for reading.

The problem of the librarianship in the Brazilian context is in the backward mentality of a large number of librarians, who present themselves as small authorities: owners of public spaces; reproducing blind sclerotic standards; slaves of cataloging records and closed systems consulting; servile followers of the codes (and not of the concrete ways of life); zombies of compartmentalized spaces; alienated puppets that only work at the touch of bureaucracy, who are unable to leave the rusty rails of the technicism; weak people who live behind the barriers of their branches; human beings that are not used to dialogue; carbon copies of authoritarian totems and player of sameness, whose only challenge in life is to know when the retirement will come out in order to continue to do nothing from the nothing they ever did. (Silva, 1999, p.99, my translation)

The words of Silva (1999) can provoke and seem to be abrupt, but they unfortunately reveal characteristics that still exist in some professional librarians, who care a lot about the technique and less with the practice of information dissemination, the training of readers, developing relationships with the users, and with their social role. It is evident that the history of libraries in Brazil contributed to some of these dispositions of the librarians: their authority had ended as well as their work had been discontinued.

Besides, the courses in librarianship still have on their curricula a large workload of technical disciplines. Souza (1996, p 51, my translation) suggests that the schools of librarianship 'do not simply limit the training of the technical, instrumental, and dumb-down contents only, but they ministry of content simply technical, instrumental, idiotizantes, but they must move forward through the historical, philosophical, political contents, etc.' Yet according to Souza (1996), this could give to the librarian an understanding of his/her social value.

Burke (2003, p.57, my translation) emphasizes that the librarians should be 'agents for the advancement of universal knowledge' and Mattelart (2002, p.137, my translation) discusses that 'there are not enough exhortations that insist on the urgency to 'actively encourage the acquisition of knowledge and skills' in order to 'transform the emerging information society into a knowledge society'. It is possible that the librarian who is committed to his/her social role can contribute to this transformation.

\section{Methodological Procedures}

This research is a case study of exploratory and descriptive nature. As it is an investigation of an empirical research, its goal is the formulation of a problem or questions. In addition to that, it also aims at describing certain phenomenon, in this case, if the librarians of the Fls recognize their social role. The study is delimited because it analyzes issues relating to one of the Fls. To Chizzotti (2008, p. 102, my translation), the case study is a "comprehensive characterization to describe a variety of researches that collect and record data in a 
particular case or several cases in order to organize an ordered and critical report of an experience; or assess it critically, aiming to make decisions about itself or propose a transformation. Gil (2008, p. 57-58) corroborates this idea by presenting the case study as "characterized by deep and exhaustive study of one or a few objects, in order to allow a broad and detailed knowledge, [... ] that aims at describing the context of situation in which this specific research is being carried out.

Data was collected using a questionnaire with open and closed questions, which was sent via e-mail to all the librarians who worked in the Fls for more than one year. Out of eight questionnaires sent, only one was not answered. It is important to note that fifteen librarians currently work in this Fls, i.e in less than a year it hired seven more librarians.

\section{A Closer Look of the Librarians}

In this section, I present a closer look of the librarians at their social roles, according to a survey data collected in this research. Librarians are properly denominated by: L1, L2, L3, L4, L5, L6 and L7, in which L stands for Librarian.

As previously mentioned, seven librarians participated in this research by responding the questionnaires. Out of these seven librarians, five have worked in the FI between one and four years, one has worked there for more than 18 years, and one librarian has been working there for 25 years. Four of them chose to be professional librarians because they love to read and feel fulfilled with the chosen profession. In order to understand the social role of the librarian, a research question was asked of the partipants: do you agree or disagree that the librarian profession has its social role? Justify your answer.

The participants answer the question as follows:

L1: I agree. The role of the librarian goes beyond the walls of the library and the library's collection. The library also has the mission to reach the local community, promoting outreach programs that contribute to the spread of information and knowledge through projects that encourage reading, storytelling, literary soirees, etc. I would appreciate if we could offer reading groups, story telling to the external community.

L2: I agree. Because it helps a lot in the cultural and intellectual development of the individual.

L3: I agree, because we have the tools to help the users find the answers by themselves.

L4: I totally agree, because every profession has its social role, and the librarians particularly of the area of education have a very emblematic social role: they have the duty to encourage a child in elementary school or a university adult to behave in a critical way with regard to their research, decisions, choices, and attitudes.

L5: I agree. Nowadays, the information is essential. If you have updated information quickly, it means a big difference in the life of the user.

L6: I totally agree. One of the examples refers to the educational role as well as the ways of use of information sources in an ethical manner, the encouragement of reading, research, and extension, etc.

L7: I agree, the librarian is not limited to the technical processing of books, he/she must participate in activities that encourage reading among its users, that also promotes qualified scientific research, and mainly engage in outreach activities in the local community. The 
librarian should also look to work together with other libraries in the region to boost the quality of the regional education.

Among the actions, activities, and services offered by those libraries, the following stand out: six libraries offer a guided tour; five promote training for users (CAPES Journal Gateway and how to use the automated collection management system); three of those libraries hold the Selective Dissemination of Information (DSI). Besides, other activities can also be mentioned: two libraries hold reading circles, two have storytelling, and only one of the libraries holds literary soirees, study groups, and activities alluding to National Book and Library Week.

It is important to note that there are other activities that the library offers that may contribute to the use, analysis, assessment, and information search such as: activities with groups of students related to the disciplines of literature and methodology; guided reading groups in the library which may help struggling readers, and guidance of research and extension programs.

\section{Final Remarks and Suggestions}

This case study presented some data research that allow to understand, analyze, and investigate how the librarians of the Federal Institute of Technology, Education and Science think and believe their social roles are. It was noticed that all the participants recognize the social role of the librarian profession, and that this role is linked not only to the activities performed in the library and to the direct users of the library, but also to the users beyond the walls of the library, i.e. the community users.

Librarians understand that their social role is directly linked to the performance of actions that enable the development of cognitive skills related to information: providing opportunities for children, young people, and adults to behave in a critical and investigative manner toward their decisions, research, choices, and attitudes.

These professionals have an understanding that their profession is eminently social: they should encourage reading, foster research, provide regional development. Additionally, librarians should provide cultural and intellectual development of the individual and the dissemination of information.

The activities and actions of user training, guided tours, selective dissemination of information, storytelling, stimulating research and reading, and reading groups show that librarians act according to what they recognize.

According to UNESCO (1997, p.9, my translation) 'we know that people's behavior is more strongly determined by motivation than by proper skills. Motivations not only put skills into action as they lead to building skills'.

Finally, it is believed that carrying out research such as this may encourage librarians from other libraries schools to demystify and recognize their social role. In addition to that, these professionals can motivate communities and people to develop their skills; especially the development of cognitive skills related to searching for, finding, using, assessing, disseminating, and understanding information.

Despite knowing that the reality of school libraries in Brazil is not the best, and to some extent in several other libraries in the world, it may be necessary to find different ways and alternatives to change the current situation. Perhaps, the work of the librarians in the Federal Institutes' libraries may be a path for a better change in the information society we live in. 


\section{References}

Almeida Júnior, O. F. de. (2000). Profissional da informação: entre o espírito e a produção. In: VALENTIM, Marta Lígia Pomim (Org.). O profissional da informação: formação, perfil e atuação profissional. São Paulo: Polis, p. 31-51.

Almeida Júnior, O. F. de. (2004). Profissional bibliotecário: um pacto com o excludente. In: BAPTISTA, Sofia Galvão; MUELLER, Suzana Pinheiro Machado (Org.). Profissional da informação: o espaço de trabalho. Brasília: Thesaurus, p. 70-86.

Baptista, D. M. (2009). Entre a informação e o sonho: o espaço da biblioteca contemporânea. Informação e Sociedade, João Pessoa, 19(1), 19-27.

BRASIL. Ministério da Educação. (2005). Instituto Nacional de Estudos e Pesquisas Educacionais Anísio Teixeira. Informativo do Inep, Brasília, ano 3, n. 74. Retrieved September 12, 2009, from http://www.inep.gov.br/informativo/pdf/informativo74.pdf

BRASIL. Ministério da Educação. (2008a). Programa Nacional Biblioteca da Escola (PNBE): leitura e bibliotecas nas escolas públicas brasileiras. Brasília: Ministério da Educação.

BRASIL. (2008b). Lei n. 11.892, de 29 de dezembro de 2008. Institui a Rede Federal de Educação Profissional, Científica e Tecnológica, cria os Institutos Federais de Educação, Ciência e Tecnologia, e dá outras providências. Diário Oficial da União, Brasília. Retrieved January 15th, 2009, from http://www.in.gov.br

BRASIL. Ministério da Educação. (2008c). Institutos Federais de Ciência , Educação e Tecnologia: concepções e diretrizes. Retrieved October 2, 2012, from http://portal.mec.gov.br/setec/arquivos/pdf3/ifets_livreto.pdf

Burke, P. (2003). Uma história social do conhecimento: de Gutenberg a Diderot. Rio de Janeiro: Zorge Zahar.

Carvalho, D. de Q. (1970). Biblioteca de escolas técnicas industriais: manual de organização e funcionamento. Brasília: Fundação IBGE.

Chizzotti, A. (2008). Pesquisa em ciências humanas e sociais. 9. ed. São Paulo: Cortez.

Dante, G. P. (2000). Perfil del profesional de información del nuevo milênio. In: VALENTIM, Marta Pomim. Profissionais da informação: formação, perfil e atuação profissional. São Paulo: Polis, p. 91-105.

FÓRUM NACIONAL DE BIBLIOTECÁRIOS DOS INSTITUTOS FEDERAIS, VI. (2011). Relatório do VI Fórum Nacional de Bibliotecários dos Institutos Federais de Educação, Ciência e Tecnologia. Petrolina, Instituto Federal do Sertão Pernambucano.

Gil, A. C. (2008). Métodos e técnicas de pesquisa social. 6. ed. São Paulo: Atlas.

Luz, C. (2007). Bibliotecas na agenda: uma questão importante para a sociedade contemporânea. Revista Brasileira de Biblioteconomia e Documentação, São Paulo, v.3, n.2, p.14-33.

Mattelart, A. (2002). História da sociedade da informação. São Paulo: Edições Loyola.

Moutinho, S. O. M., \& Lustosa, I. T. (2011). As bibliotecas dos Institutos Federais frente às 
novas demandas gerenciais e informacionais causadas pela Lei 11.892/2008. In: FÓRUM NACIONAL DE BIBLIOTECÁRIOS DOS INSTITUTOS FEDERAIS, 6. outubro, 2011, Petrolina. Anais. Petrolina: Instituto Federal do Sertão Pernambucano.

UNESCO. (1997). Organização das Nações Unidas para a Educação, Ciência e Cultura. Habilidades cognitivas e competências sociais. Laboratório Latinoamericano de Evaluación de la calidad de la educación. Série Documentos, OREALC/1997/OI/H/7. Retrieved June 20, 2013, from http://unesdoc.unesco.org/images/0018/001836/183655por.pdf.

Pacheco, E. (2009). Os Institutos Federais: uma revolução na educação profissional e tecnológica. Brasília: Ministério da Educação, 2009.

Paiva, F. S. De, \& Rodrigues, M. C. (2008). Habilidades de vida: uma estratégia preventiva ao consumo de substâncias psicoativas no contexto educativo. Revista Estudos e Pesquisas em Psicologia, UERJ, ano 8, n.3, p. 672-684. Retrieved April 2, 2013, from http://www.revispsi.uerj.br/v8n3/artigos/pdf/v8n3a09.pdf

Santos, C. A. da S, Hoffmann, W. A. M., \& Boccato, V. R. C. (2011). Os múltiplos olhares para as bibliotecas dos Institutos Federais de Educação, Ciência e Tecnologia. In: FÓRUM NACIONAL DE BIBLIOTECÁRIOS DOS INSTITUTOS FEDERAIS, 6. outubro, 2011, Petrolina. Anais. Petrolina: Instituto Federal do Sertão Pernambucano.

Silva, E. L. Da, \& Cunha, M. V. da. (2002). A formação profissional no século XXI: desafios e dilemas. Ciência da Informação, Brasília, v. 31, n. 3, p. 77-82. Retrieved June 28, 2009 from http://www.scielo.br/pdf/ci/v31n3/a08v31n3.pdf

Silva, E. T. da. (1999). De olhos abertos: reflexões sobre o desenvolvimento da leitura no Brasil. 2. ed. São Paulo: Ática.

Souza, F. da C. de. (1997). Biblioteconomia no Brasil: profissão e educação. Florianópolis: Associação Catarinense de Bibliotecários: Biblioteca Universitária da UFSC.

Souza, F. da C. de. (1996). Ensina-se corretamente o que se ensina a quem vai ser bibliotecário? Revista ACB: biblioteconomia em Santa Catarina, Florianópolis, v.1, n.1.

Valentim, M. L. P. (Org.). (2000). O profissional da informação: formação, perfil e atuação profissional. São Paulo: Polis.

Vandenbos, G. R. (Org.). (2010). Dicionário de psicologia: American Psyshological Association : APA. Porto Alegre: Artmed.

\section{Biographical note}

Caroline da Rosa Ferreira Becker is a librarian at the Federal Institute of Education, Science and Technology of Santa Catarina - Campus Rio do Sul. She also holds a Master Degree in Information Science from Federal University of Santa Catarina (UFSC). She is a Specialist in Education: Reading, Literacy, and Literature and also a Professor at some Specialization Courses. Ms. Becker is an Advisor of the Regional Library of Santa Catarina and Coordinator of the Management of Libraries Working Group (CBBI).

More information can be found on her Academic Resume at:

http://lattes.cnpq.br/3807216819421837 